\title{
University Social Responsibility Advancement in Mexico's Higher Education Institutions: A Comparative Study
}

\author{
Pedro Javier Martínez Ramos, Hilda Cecilia Escobedo Cisneros, Myrna Isela García Bencomo, \\ José Gerardo Reyes López
}

Facultad de Contaduría y Administración, Universidad Autónoma de Chihuahua, Chihuahua, México

Email: pmartinr@uach.mx,hescobed@uach.mx,mygarcia@uach.mx,jreyes@uach.mx

How to cite this paper: Ramos, P. J. M., Cisneros, H. C. E., Bencomo, M. I. G., \& López, J. G. R. (2020). University Social Responsibility Advancement in Mexico's Higher Education Institutions: A Comparative Study. Open Journal of Business and Management, 8, 2029-2047. https://doi.org/10.4236/ojbm.2020.85124

Received: July 14, 2020

Accepted: August 30, 2020

Published: September 2, 2020

Copyright $\odot 2020$ by author(s) and Scientific Research Publishing Inc. This work is licensed under the Creative Commons Attribution International License (CC BY 4.0).

http://creativecommons.org/licenses/by/4.0/ (c) (i) Open Access

\begin{abstract}
In recent times, the importance of the responsibility of universities has been highlighted. The objectives of the research focused on making a diagnosis of the progress in the transversal management of University Social Responsibility (RSU) in Higher Education Institutions (IES), 2 public ones, the Autonomous University of Chihuahua (UACH), and University of Colima (UCol); and 2 private ones, the Universidad de Monterrey (UDEM); and the Instituto Tecnológico y de Estudios Superiores de Monterrey (ITESM), Monterrey campus, to compare the performance in RSU of the same and to identify good practices of RSU. The nature of the research was quantitative, descriptive, non-experimental and transectional. The method was based on a 2019 random survey of 201 university executives. A measurement instrument was applied that divides the RSU macrovariable into 4 areas of action and 12 compliance goals. The stated objectives were met and it was found that the level of RSU progress in ITESM was 3.27, in UDEM it was 4.24, in UCol it was 3.52, and in $\mathrm{UACH}$ it was 2.78 .
\end{abstract}

\section{Keywords}

University Social Responsibility, Organizational Management, Training, Cognition, Social Participation

\section{Introduction}

The huge challenges that the environment poses to higher education institutions (HEIs) have forced them to evolve rapidly in recent years. The important question that today's society asks universities is: What are their roles in solving the 
great social, environmental, and economic problems, and in the development of global and digital citizens that the 21st century demands? (Pancenza \& Silva, 2013); (Mendoza, Salas, \& López, 2015); (Aldeanueva \& Jiménez, 2013); (Aldeanueva, 2015). The main challenges that higher education is facing are development of the citizenry, which provides students with the opportunity of developing their capacities with high social responsibility, increasing coverage in higher education, and decreased funding, which has resulted in inconsistency in academic consolidation (Gaete, 2015; Gaete, 2011); (Pancenza \& Silva, 2013); (Gaete, 2016). The speed at which these demands emerged made it impossible for many HEIs to adapt to them, thus deteriorating the image of university versus society.

Universities are a promoter of social mobility as well as a tool to improve the quality of life of the societies in which they are developed. They are a public good, so they must assume social leadership to face inequalities and transform reality into a fairer and more inclusive one (Beltrán, Íñigo, \& Mata, 2014); (Cohen, 2007). Considering the above, it is imperative to reassess the function of the university-that new management models are creatively developed in which, from its philosophy, values, and objectives, the strategic axes of social responsibility are included, to achieve an effective social impact that is sustainable, subject to monitoring, transparency, and evaluation (Martínez \& Hernández, 2013); (López, Zalthen, \& Cervantes, 2016).

At the beginning of the 21st century, the debate on University Social Responsibility (USR) began in the context of higher education. It can be said that the first decade of this century has been very prolific in the exploration of USR. Table 1 shows the most significant advances in this area.

As Table 1 shows, the effort has been considerable; however, application of the USR concept has been limited, given the demands of today's society on universities so that they take on a more active role in the construction of more ethical, sustainable, and cohesive societies. International organizations such as the UNESCO have established and ratified the importance of universities' responsibility in building social development and peace (UNESCO, 2009). Therefore, it is imperative that universities assume their role in talent training and problem solving through knowledge.

Based on all this, HEIs have understood that USR is of great relevance, which requires concrete actions by universities worldwide, and its research and application are urgent. In Mexico, USR is still under construction, and despite making important advances, there is insufficient information on it; in addition, a significant transformation of higher education has not been achieved due to lack of dissemination and systematization. Currently, there are numerous USR-related actions and experiences that need to be evaluated and documented to promote the sustainable development of HEIs. It is for these reasons that we set the following objectives: 
Table 1. Important progress vis-à-vis university social responsibility in the 21 st century.

\begin{tabular}{|c|c|c|}
\hline Agency Responsible & Contribution & Year \\
\hline $\mathrm{UN}$ & $\begin{array}{l}\text { The Global Pact is a social responsibility initiative, } \\
\text { in which, through } 10 \text { universally accepted principles } \\
\text { related to human rights, labor standards, the } \\
\text { environment, and the fight against corruption, } \\
\text { the aim is to support sustainability and inclusion. }\end{array}$ & 2000 \\
\hline $\begin{array}{l}\text { Chilean network } \\
\text { "Universidad } \\
\text { Construye País (UCP)" }\end{array}$ & $\begin{array}{l}\text { It is the first known attempt in Latin America to } \\
\text { advance USR. Its objective was to expand USR within } \\
\text { the Chilean HEIs-14 universities integrated it. }\end{array}$ & 2001 \\
\hline $\begin{array}{l}\text { USR network of the } \\
\text { Association of Universities } \\
\text { Entrusted to the Society of } \\
\text { Jesus in Latin America (AUSJAL) }\end{array}$ & $\begin{array}{l}\text { This network was established with the objective } \\
\text { that AUSJAL universities participate voluntarily } \\
\text { to strengthen the real and effective } \\
\text { institutionalization of the USR perspective. }\end{array}$ & 2003 \\
\hline $\begin{array}{c}\text { Ibero-American } \\
\text { Heads of State Summit }\end{array}$ & $\begin{array}{l}\text { The creation of an Ibero-American knowledge } \\
\text { space was proposed, which has been the basis for } \\
\text { the creation of the USR conceptual framework. }\end{array}$ & 2005 \\
\hline UNESCO & $\begin{array}{l}\text { World congress of higher education, which stipulates } \\
\text { that higher education should not only provide solid } \\
\text { competences for the world of today and tomorrow } \\
\text { but also contribute to the development of a citizenry } \\
\text { endowed with ethical principles, committed to the } \\
\text { development of peace, defense of human rights, } \\
\text { and the values of democracy. }\end{array}$ & 2009 \\
\hline $\begin{array}{l}\text { International Organization } \\
\text { for Standardization }\end{array}$ & $\begin{array}{l}\text { ISO } 26000 \text { is a guide on how organizations can } \\
\text { operate in a responsible way. This means acting in an } \\
\text { ethical and transparent manner, considering all } \\
\text { interest groups and accountability. }\end{array}$ & 2010 \\
\hline $\begin{array}{l}\text { Ibero-American meeting of } \\
\text { rectors organized by the } \\
\text { Universia network }\end{array}$ & $\begin{array}{l}\text { The Ibero-American space of knowledge has evolved } \\
\text { to become a socially responsible one. The guiding } \\
\text { thoughts of this initiative are the strategic role of } \\
\text { universities in society and the importance of } \\
\text { education, training, research, knowledge transfer, } \\
\text { and innovation for the well-being and sustainable } \\
\text { development of peoples. }\end{array}$ & 2010 \\
\hline $\mathrm{UN}$ & $\begin{array}{l}\text { World leaders adopted } 17 \text { Sustainable Development } \\
\text { Goals, to eradicate poverty, protect the planet, and } \\
\text { ensure sustainability for all. Each has a specific set of } \\
\text { objectives that must be achieved in the next } 15 \text { years. }\end{array}$ & 2015 \\
\hline $\begin{array}{l}\text { National Association of } \\
\text { Universities and Higher } \\
\text { Education Institutions } \\
\text { (ANUIES) }\end{array}$ & $\begin{array}{l}\text { The ANUIES, in the plan of } 2015 \text {, proposed to } \\
\text { hold regional forums on USR. In these events, } \\
\text { the objective of focusing on advances and } \\
\text { documenting the areas of opportunity was } \\
\text { proposed to realize the educational process. }\end{array}$ & 2015 \\
\hline $\begin{array}{l}\text { Union of University Social } \\
\text { Responsibility in Latin } \\
\text { America (URSULA) }\end{array}$ & $\begin{array}{l}\text { URSULA proposes the creation of a group of } \\
\text { academics (made up of } 139 \text { universities) that } \\
\text { shares and proposes good practices of MSW and } \\
\text { innovative and sustainable management models. } \\
\text { It has coordinated forums and research in Latin } \\
\text { America since } 2018 \text { - the USR-related diagnosis of } \\
\text { the region shows progress in the areas of } \\
\text { Organizational Management, Training, } \\
\text { Cognition, and Social Participation. }\end{array}$ & 2016 \\
\hline
\end{tabular}




\section{Continued}

\begin{tabular}{clc}
\hline $\begin{array}{c}\text { Mexican Observatory of } \\
\text { University Social }\end{array}$ & $\begin{array}{l}\text { OMERSU was created with 32 affiliated universities } \\
\text { on the direction of the Universidad Autónoma de } \\
\text { Yucatán. Its main objective is to strengthen the } \\
\text { responsibility (OMERSU) }\end{array}$ & 2016 \\
National Association of Faculties \\
$\begin{array}{c}\text { and Schools of Accounting and } \\
\text { Administration (ANFECA) }\end{array}$ & $\begin{array}{l}\text { ANFECA promotes a USR hallmark among business } \\
\text { schools in Mexico; HEIs must demonstrate their } \\
\text { commitment to promote quality and performance } \\
\text { ethics in favor of responsible management. }\end{array}$ & \multirow{2}{*}{2016} \\
\hline
\end{tabular}

Note. Own elaboration based on (Moreno \& Gutiérrez, 2018); (Naciones Unidas, 2015); (Martínez \& Hernández, 2013); (Schwalb, Prialé, \& Vallaeys, 2019); (Vallaeys \& Solano, Ursula, 2018); (Vallaeys, Solano , \& Oliveira, 2019); (Martínez, Escobedo, García, \& López, 2018); USR = University Social Responsibility, HEIs = higher education institutions.

- To carry out a diagnosis of the level of progress in the management of USR (Vallaeys \& Solano, 2018); (Vallaeys, Solano, \& Oliveira, 2019) in two public HEIs (Universidad Autónoma de Chihuahua (UACH) and Universidad de Colima (UCol)) and two private ones (Instituto Tecnológico de Estudios Superiores de Monterrey (ITESM), Monterrey campus, and Universidad de Monterrey (UDEM)).

- To compare the performance of the diagnosed HEIs vis-à-vis USR.

- To identify good USR practices in the diagnosed HEIs.

\section{Literature Review}

Social responsibility has its origins in the work of companies; however, it is possible to apply it to the functioning of universities, especially because HEIs are increasing in number and must establish relationships with society, allowing them to consolidate their teaching and research work. Such a task sees an increase in the interest it generates in different people, groups, the state, the market, and civil society, named under this approach as stakeholders. However, the analysis and research of social responsibility within universities, as well as the application of the concept, is less than that in companies. This is due to the fact that university academics who investigate these issues, when they occasionally direct their attention to the internal workings of their respective institutions, focus their analysis on what they teach rather than the appropriate and ethical behaviors that university institutions must exhibit in matters of social responsibility (Gaete, 2011). Hence, universities, faced with new processes and social demands, are called on to become aware of their importance in society through USR, and seek to generate sustained action for the benefit of society and its stakeholders (Schwalb, Prialé, \& Vallaeys, 2019); (Vallaeys \& Solano, Ursula, 2018); (Vallaeys, Solano, \& Oliveira, 2019). In recent years, analysis of the relationship between university and society has been promoted, pushing for the incorporation of USR programs that provide solutions to mass access to higher education, progressive decrease in state funding for universities, and growing interest of the economy and society in the knowledge imparted by universities 
(Gaete, 2016); (Schwalb, Prialé, \& Vallaeys, 2019).

USR is mainly distinguished from social responsibility by promoting a formative academic ethic of personality (Martínez \& Hernández, 2013). HEIs, through USR, seek a professional to develop awareness and a service ethic that promote and elevate the societies they are in. The university, then, must contribute toward the solutions of the problems that afflict the environment, by promoting cooperation spaces, teaching and research activities, and redesign of study plans, among other things (Schwalb, Prialé, \& Vallaeys, 2019); (UNESCO, 2009); (García \& Vega, 2019).

HEIs' ability to adapt to changes has been constantly challenged; the responses obtained, however, have been slow and not as pertinent (Gaete, 2016); (Dominguez, 2009). When comparing the adoption of social responsibility programs in different fields, it is an indisputable fact that the business sector leads the way. Particularly at the university level, the implementation of social responsibility in its management systems has been limited despite its vocation and social orientation (Schwalb, Prialé, \& Vallaeys, 2019); (Andrades \& Larrán, 2015). Universities, which are organizations that provide services to the community, do not always see the need to inform potential stakeholders of their activities through their social responsibility programs. Likewise, there is no specific guide that helps in the successful implementation of these programs, or that ensures quality in those already implemented. Most of the current programs lack aspects related to activities within the organization, besides environmental, social, and human rights aspects (Pancenza \& Silva, 2013); (Cohen, 2007).

However, it is of utmost importance to promote the adoption of social responsibility programs in these institutions, since universities contribute significantly to the economic and social development of societies that maintain and promote them (Aldeanueva \& Jiménez, 2013); (Aldeanueva, 2015). Considering all this, it is imperative that universities develop new management models in which, from their philosophy, values, and objectives, the strategic axes of social responsibility are included (Aldeanueva, 2015); (López, Zalthen, \& Cervantes, 2016). In Mexico, significant efforts have been made for universities to rediscover their social commitment, highlighting the efforts of the National Association of Universities and Institutions of Higher Education, Mexican Observatory of University Social Responsibility (OMERSU), and National Association of Faculties and Schools of Accounting and Administration (ANFECA) (Martínez, Escobedo, García, \& López, 2018). OMERSU aims to promote the analysis, debate, and full understanding of USR in Mexico's HEIs, favoring its monitoring and evaluation, and continuous improvement in the results achieved. Meanwhile, the National Coordination of University Social Responsibility of ANFECA seeks to promote the quality and ethics of the performance of business schools and faculties through responsible management, launching the first call for obtaining the USR Distinctive in 2016, with which it intends to recognize universities for their contributions to management, training, research, and social participation (López, Zalthen, \& Cervantes, 2016); (Martínez, Escobedo, García, \& López, 
2018).

Furthermore, the implementation of USR in universities has made notable differences, according to its public or private nature. According to (Olarte \& Ríos, 2015), USR in public universities focuses on the relevant internal aspects of their organization. In such universities, the progress of USR is mainly observed in the periodic review of their curricula and their development; in communication policies to strengthen internal relationships between teachers, administrative staff, and students; in the management of welfare policies for the academic and administrative communities; in research with relevance for inclusion, training, and citizenry; and, finally, it is incorporated in various transformations at the organizational level oriented to the defense and care of its natural environment, responsible consumption, as well as transformation toward a green or sustainable campus.

Private universities, on the other hand, focus on the externalities, such as promoting relations with interest groups, namely government entities, suppliers, and ONGs, among others. Moreover, in the area of USR, actions of cooperation, philanthropy, care for the environment with exchange of resources, and participation in the transformation and formulation of quality institutional policies and competitiveness standards that ensure their relevance in the educational system stand out, and likewise, its profitability (Olarte \& Ríos, 2015); (Rusinko, 2010).

It is very important to highlight that for USR to have a positive impact on education, and consequently on the sustainable development of societies, the synergy of HEIs (private and public) is necessary, as is greater dissemination of practices vis-à-vis USR. It is only through consensus and collaboration of the institutions that USR can have a significant impact on public policies on higher education, the design and destination of universities, socially responsible research and innovation, evaluation agencies and accreditation, and in the international integration of higher education (Schwalb, Prialé, \& Vallaeys, 2019); (Aldeanueva, 2015).

\section{Method}

This research is empirical, applied, non-experimental, and cross-sectional, with a mixed and descriptive approach. We worked with the managers of ITESM, UDEM, UACH, and UCol. The unit of analysis was the career directors of the institutions-49 from ITESM, 47 from UDEM, 52 from UACH, and 53 from UCol, a total of 201. Given the size of the population, it was decided to apply the instrument of investigation to all during the months of January to June 2019.

The measurement instrument (Vallaeys \& Solano, 2018); (Vallaeys, Solano, \& Oliveira, 2019) assigns a numerical value to the progress of USR, which is analyzed in four areas of action that demonstrate the achievement of 12 goals of socially responsible performance, which include some compliance indicators; these are shown in Table 2. 
Table 2. Operationalization of the university social responsibility macro variable.

\begin{tabular}{|c|c|c|}
\hline Ambit & Performance Goals & $\begin{array}{l}\text { Compliance } \\
\text { Indicators }\end{array}$ \\
\hline $\begin{array}{c}\text { Organizational } \\
\text { Management }(\mathrm{OM})\end{array}$ & $\begin{array}{l}\text { OM-Good work environment } \\
\text { OM-Ecological campus } \\
\text { OM-Ethics and transparency }\end{array}$ & 18 \\
\hline Training (T) & $\begin{array}{l}\text { T-Project-based learning } \\
\text { T-Inclusion of SDGs } \\
\text { T-Connections with external actors }\end{array}$ & 17 \\
\hline Cognition (C) & $\begin{array}{l}\text { C-Inter and transdisciplinarity } \\
\text { C-Research in and with the community } \\
\text { C-Production and dissemination of useful knowledge }\end{array}$ & 16 \\
\hline Social Participation (SP) & $\begin{array}{l}\text { SP-SP-F-I integration } \\
\text { SP-Co-created projects } \\
\text { SP-Participation in external agenda }\end{array}$ & 15 \\
\hline
\end{tabular}

Note. Own elaboration based on (Vallaeys \& Solano, Ursula, 2018); (Vallaeys, Solano, \& Oliveira, 2019); SDGs = Sustainable Development Goals.

As Table 2 shows, the compliance indicators total 66. These were evaluated using an applied measurement scale with five levels of compliance (Table 3).

If the university director self-scored at level 4 or 5 , evidence of the good policies and/or initiatives that he/she has instituted was requested. The procedure followed was that the self-diagnosis was sent by email to the career coordinators, and then, the respondents were asked to consider the following recommendations: if necessary, to ask for advice in completing the self-diagnosis; in case of evaluating a certain indicator with a compliance level of 4 or 5 , to present evidence that supports what has been said; and to fill out the questionnaire personally and honestly with the knowledge acquired.

\section{Results}

The results were analyzed according to the objectives set, and the measurement instrument was applied randomly considering only the managers in the participating universities. The results are described below.

The first objective was to diagnose the level of progress in the management of USR in the participating Mexican HEIs. Table 4 shows the results obtained.

As Table 4 shows, according to the average, the goals with the most progress are in the OM field-ethics and transparency (4.05) and good work environment (3.98) - followed by the goal of research in and with the community (3.82) in the field of Cognition. In the same way, the goals with the greatest area of perceived opportunity are in the fields of Training-inclusion of SDGs (Sustainable Development Goals) (2.53) and project-based learning (3.04) - and Social Participation-participation in external agenda (3.08). It can also be seen that, in general terms, UDEM has the best results in almost all the goals, while UACH shows the least progress in the goals' management. 
Table 3. Criteria for evaluating indicators.

\begin{tabular}{cl}
\hline Level & \multicolumn{1}{c}{ Details } \\
\hline 1 & It has not been contemplated. \\
2 & Isolated initiatives have been developed. \\
3 & There are sustained efforts to achieve this. \\
4 & The university has institutionalized the issue as a policy and achieved some results. \\
5 & Our transversal policy has systematized impacts and results. \\
\hline
\end{tabular}

Note. Own elaboration based on (Vallaeys \& Solano, Ursula, 2018); (Vallaeys, Solano, \& Oliveira, 2019).

Table 4. Progress level of university social responsibility in participating Mexican Universities.

\begin{tabular}{lccccc}
\hline \multicolumn{1}{c}{ Ambit/Goal } & ITESM & UDEM & UACH & UCol & Average \\
\hline OM-Good work environment & 4.11 & 4.11 & 3.57 & 4.14 & 3.98 \\
OM-Ecological campus & 3.04 & 4.10 & 2.20 & 3.00 & 3.09 \\
OM-Ethics and transparency & 4.05 & 4.65 & 3.50 & 4.00 & 4.05 \\
Organizational Management (OM) & 3.73 & 4.29 & 3.09 & 3.71 & 3.71 \\
T-Project-based learning & 2.87 & 4.45 & 2.14 & 2.71 & 3.04 \\
T-Inclusion of SDGs & 2.42 & 4.04 & 2.00 & 1.67 & 2.53 \\
T-Connections with external actors & 3.52 & 4.41 & 2.50 & 3.25 & 3.42 \\
Training (T) & 2.94 & 4.30 & 2.21 & 2.54 & 3.00 \\
C-Inter and transdisciplinarity & 3.50 & 3.90 & 3.00 & 3.60 & 3.50 \\
C-Research in and with the community & 3.29 & 4.58 & 3.00 & 4.40 & 3.82 \\
C-Production and dissemination of useful knowledge & 3.09 & 4.17 & 2.67 & 4.17 & 3.52 \\
Cognition (C) & 3.29 & 4.22 & 2.89 & 4.06 & 3.61 \\
SP-SP-T-C integration & 3.36 & 4.25 & 3.50 & 3.70 & 3.70 \\
SP-Co-created projects & 2.91 & 4.25 & 2.83 & 5.00 & 3.75 \\
SP-Participation in external agenda & 3.05 & 4.25 & 2.40 & 2.60 & 3.08 \\
Social Participation (SP) & 3.11 & 4.25 & 2.91 & 3.77 & 3.51 \\
\hline
\end{tabular}

Note. Own elaboration based on (Vallaeys \& Solano, 2018); SDGs = Sustainable Development Goals.

Regarding the objective of comparing the USR performance of the participating public and private HEIs in Mexico, the applied measurement instrument used was from a Latin American study carried out in 2018 and 2019 (Vallaeys \& Solano, 2018); (Vallaeys, Solano, \& Oliveira, 2019). For practical reasons, only the results of the 2018 research are addressed, which was led by the Unión de Responsabilidad Social Universitaria de Latinoamérica (URSULA), in which 60 universities from nine Latin American countries (Argentina, Brazil, Bolivia, Chile, Colombia, Costa Rica, Mexico, Peru, and Uruguay) participated. The main objective of the aforementioned research was to find out the institutional advances in the transversal management of the participating universities' USR; 
its results allowed us to obtain the averages of the USR performance in Latin America. In Mexico, 12 universities (eight public and four private)-located in Chihuahua, Colima, Culiacán, Guadalajara, La Paz, Morelia, Puebla, Tuxtla-Gutiérrez, Hidalgo, Monterrey, and León-had participated; the average USR in Mexico was obtained from these. On the other hand, in the present study, as already mentioned, the USR performance of the four aforementioned universities was evaluated. The results obtained are presented in Table 5.

As Table 5 shows, the strengths of USR in Latin America, Mexico, and the private universities are the goals of a good work environment and ethics and transparency, in the OM field; likewise, in public universities, the perceived strengths are co-created projects and a good work environment. The main area of opportunity perceived by all was the inclusion of SDGs, project-based learning, and ecological campus.

Additionally, the management of USR can be seen in Figure 1, which highlights that the progress of the private universities participating in the research (Vallaeys \& Solano, Ursula, 2018); (Vallaeys, Solano, \& Oliveira, 2019) is one of the most significant in the Latin American region.

Figure 1 shows that the public universities (UACH and UCol), in seven of the goals, are above the averages for Latin America and Mexico. From figure, we can see that the public universities are lower than Latin America and Mexico at the $\mathrm{T}$ inclusion of SDGS. To achieve the objective of identifying the actions taken by the participating universities to improve USR performance, and following the methodology, the directors participating in the research shared several actions that have been carried out in recent years. These initiatives can be considered as good practices and implemented by any HEI that aspires to be socially responsible. The most valuable are categorized below.

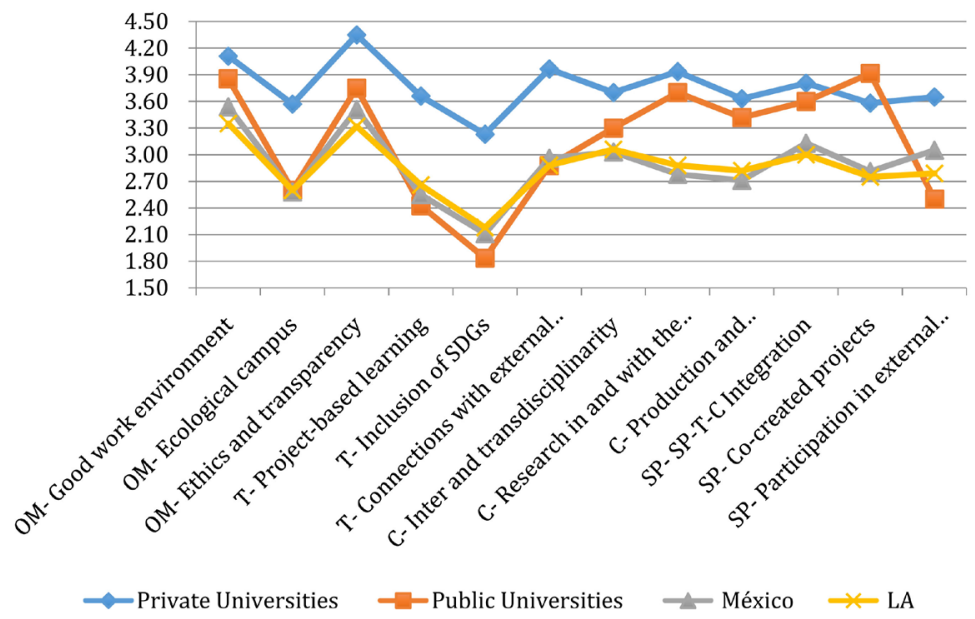

Figure 1. Comparative analysis of the level of University Social Responsibility in Latin America, Mexico, and public and private universities of Mexico. Note. Own elaboration based on (Vallaeys \& Solano, 2018) (Vallaeys, Solano, \& Oliveira, 2019); OM = Organizational Management, $\mathrm{T}=$ Training, $\mathrm{C}=$ Cognition, $\mathrm{SP}=$ Social Participation, SDGs = Sustainable Development Goals, LA = Latin America. 
Table 5. Average level of university social responsibility in private (2) and public universities (2) in Mexico, in Mexico overall, and in Latin America.

\begin{tabular}{|c|c|c|c|c|}
\hline \multirow{3}{*}{ Ambit/Goal } & \multicolumn{4}{|c|}{ Average USR Performance } \\
\hline & $\begin{array}{c}\text { Private } \\
\text { Universities }\end{array}$ & $\begin{array}{c}\text { Public } \\
\text { Universities }\end{array}$ & \multirow[t]{2}{*}{ Mexico } & \multirow[t]{2}{*}{ LA } \\
\hline & \multicolumn{2}{|c|}{ Mexico } & & \\
\hline OM-Good work environment & 4.11 & 3.86 & 3.54 & 3.35 \\
\hline OM-Ecological campus & 3.57 & 2.60 & 2.58 & 2.60 \\
\hline OM-Ethics and transparency & 4.35 & 3.75 & 3.51 & 3.32 \\
\hline T-Project-based learning & 3.66 & 2.43 & 2.55 & 2.66 \\
\hline T-Inclusion of SDGs & 3.23 & 1.84 & 2.11 & 2.18 \\
\hline T-Connections with external actors & 3.97 & 2.88 & 2.96 & 2.88 \\
\hline C-Inter and transdisciplinarity & 3.70 & 3.30 & 3.03 & 3.06 \\
\hline C-Research in and with the community & 3.94 & 3.70 & 2.78 & 2.88 \\
\hline C-Production and dissemination of useful knowledge & 3.63 & 3.42 & 2.71 & 2.82 \\
\hline SP-SP-F-I integration & 3.81 & 3.60 & 3.13 & 3.00 \\
\hline SP-Co-created projects & 3.58 & 3.92 & 2.81 & 2.75 \\
\hline SP-Participation in external agenda & 3.65 & 2.50 & 3.05 & 2.79 \\
\hline
\end{tabular}

\subsection{Organizational Management}

This comprises a good work environment, ecological campus, and ethics and transparency. Figure 2 shows the comparative results of the participating universities in the OM field. All perform well vis-à-vis these goals, when compared with the averages for Mexico and Latin America.

This field includes all aspects of how a socially responsible university should be organized and managed. Under it, the following initiatives were identified:

- Code of ethics that offers a frame of reference and identity to those who are part of the institution. Each collaborator receives training in ethics and values. There is a written compliance commitment, which is renewed annually.

- Ethical line, which allows confidential reporting of situations or behaviors that represent a breach of the code of ethics. Defenders of university rights are installed.

- General guidelines for gender equality, which are mandatory; their purpose is to establish rules, as an indispensable and necessary condition, to achieve and regulate gender equality.

- Action protocols for the prevention of gender violence, which seek to prevent, address, investigate, and punish acts of violence that occur among members of the university community. 


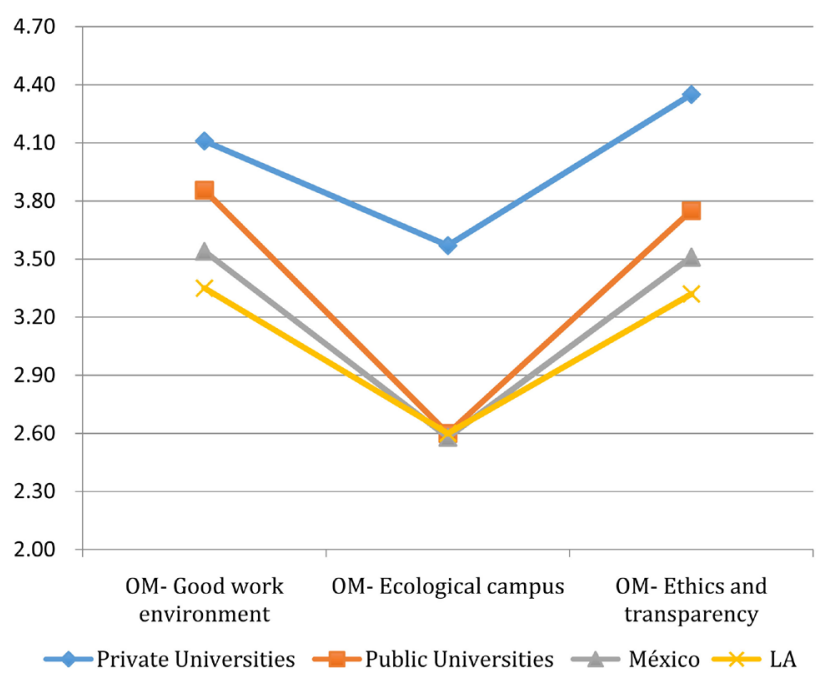

Figure 2. Comparative results of the participating universities in organizational management. Note. Own elaboration based on (Vallaeys \& Solano, 2018); OM = Organizational Management, LA = Latin America.

- There are dependencies of the USR unit, which allows the topics to be promoted in a dynamic and constant way.

- Continuing education programs as well as welfare services (health, arts, sports, etc.) are provided to workers. In addition, the benefits granted are far superior to the law, such as maternity care permits, $100 \%$ scholarships to study the programs offered by the institution, savings accounts, agreements, and medical insurance, among others.

- Annual work climate improvement surveys that are prepared by an external agency.

- Admission and hiring processes by meritocracy: There are admission regulations aimed at ensuring that candidates are selected by a fair and impartial procedure.

- Sustainable campus: This initiative mainly includes the use of wastewater for irrigation and gardens, and energy saving and recycling program.

- Campaigns to promote values: It is a mechanism that strengthens the formation and development of the citizenry.

- Obtaining a distinctive family-friendly company, granted by the Ministry of Labor and Social Welfare, which accredits the institution for promoting good labor practices in matters of gender equality, prevention and tackling of workplace violence and sexual harassment, as well as actions and policies to encourage workers to attend to their family responsibilities.

- The certification of universities as $100 \%$ smoke-free spaces: This promotes the protection of and respect toward non-smokers, and compliance with the General Law against Tobacco.

\subsection{Training}

This comprises learning based on social projects, curricular inclusion of the 17 
SDGs, and connections developed with external actors. Figure 3 shows the comparative results of the participating universities in the field of Training. It highlights that private universities are above the averages and that public universities still have a lot to do in this field, especially in the inclusion of the SDGs.

In this field, which addresses the subject of professional and citizen training and how universities contribute to the development of the citizenry, best practices were identified mainly in the private institutions, given the low performance perceived in public institutions; these are listed below:

- Training program in social leadership.

- Network for the achievement of SGDs (ITESM/UNAM, School of Social Sciences and Government): This initiative was signed in March 2019 and is aimed at channeling experience and resources from the academic field, civil society, and private sector to provide innovative solutions to the core problems cited by the 17 SGDs by 2030 .

- Accreditation of The Southern Association of Colleges and Schools Commission on Colleges, which recognizes academic quality, and supports the improvement of teachers' academic credentials, progress in the teaching-learning process and its innovation, bibliographic heritage, and infrastructure, among other aspects of management.

- Collaboration agreement with the Social Union of Entrepreneurs of Mexico, which establishes UDEM as the headquarters of the training program for entrepreneurs on corporate social responsibility.

- Inclusion in the curriculum of subjects applied to service learning taken by all students. Some examples of these courses are sustainability, ethics and social responsibility in business, social entrepreneurship, culture of legality, and gender equity.

- Implementation of a Sustainability Center, whose objectives are:



Figure 3. Comparative results of the participating universities in training. Note. Own elaboration based on (Vallaeys \& Solano, 2018); T = Training, SDGs = Sustainable Development Goals, LA = Latin America. 
O To enrich university education with educational programs and awareness-raising actions to generate a sustainable culture and transformative leadership for students, through action research participation in marginalized communities.

- To strengthen the student community with sustainable development actions, and promote self-managed projects that encourage sustainability through concrete actions based on science and research, besides engaging in promotion of alliances and synergies that allow increasing said programs.

- Semester I is an experiential learning experience in which, during an academic semester, subjects are taken in modules to generate proposals and solutions to real projects or problems in companies and organizations or even in the development of a model of their own business. As a result, students focus on a purpose and strengthen their graduation skills.

\subsection{Cognition}

This comprises inter and transdisciplinarity, research in and with the community, and production and dissemination of useful knowledge. Figure 4 shows the comparative results of the participating universities in the field of Cognition. It highlights that private and public universities perform better vis-à-vis these goals, compared with the averages for Mexico and Latin America-their best performance is in research in and with the community. Analyzing the averages in this area, the participating public and private universities have taken advantage of the laws that promote interdisciplinary research in disadvantaged communities, which forms links for community work and problem solving. Above all, private universities work to disseminate knowledge that is useful, which they associate with a concept of social utility of research.

This field refers to the social relevance of knowledge and involves managing the impacts of the production and dissemination of knowledge, research, and

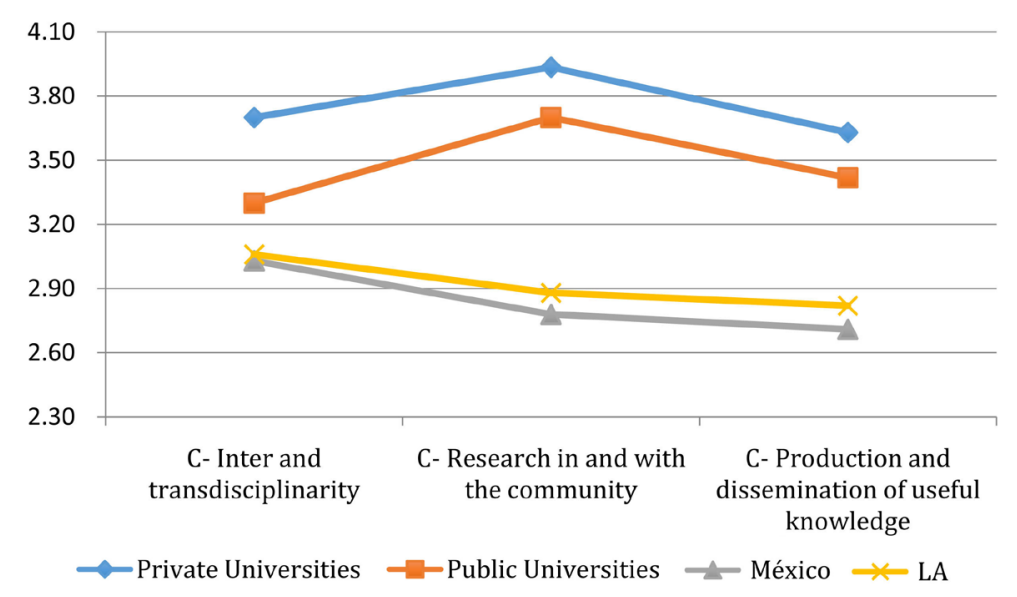

Figure 4. Comparative results of the participating universities in Cognition. Note. Own elaboration based on (Vallaeys \& Solano, 2018) (Vallaeys, Solano, \& Oliveira, 2019); C = Cognition, LA = Latin America. 
epistemological models promoted from the classroom. The best actions identified were:

- Social incubator: Social incubators are physical spaces in which students and teachers participate in person. They offer technical training and resources to students who wish to undertake social initiatives.

- Rural Mexico and Urban Mexico Program: This links a subject of the training curriculum with community work aimed at solving problems. This initiative aims to promote students' commitment to the country's social development as well as to reinforce research processes in and with the community, citizen training, and effective advocacy for the most disadvantaged.

- The CEMEX-TEC center fosters sustainability in communities through applied research, innovation, and entrepreneurship programs, creating opportunities to link with academia, civil society, and the public and private sectors, to raise the quality of life in rural and urban settings.

\subsection{Social Participation}

This comprises integration of social projection with training and research, co-created projects, lasting impact, and participation in local, national, and international development agendas. Figure 5 shows the comparative results of the participating universities in the SP field. It highlights that private and public universities perform better vis-à-vis these goals, compared with the averages for Mexico and Latin America; while public universities do not do well in the goal of participation in local, national, and international development agendas, they show the best performance in co-created projects, above even private universities.

The fourth and last field of action refers to managing the impact of university participation on the community. The best actions identified were:

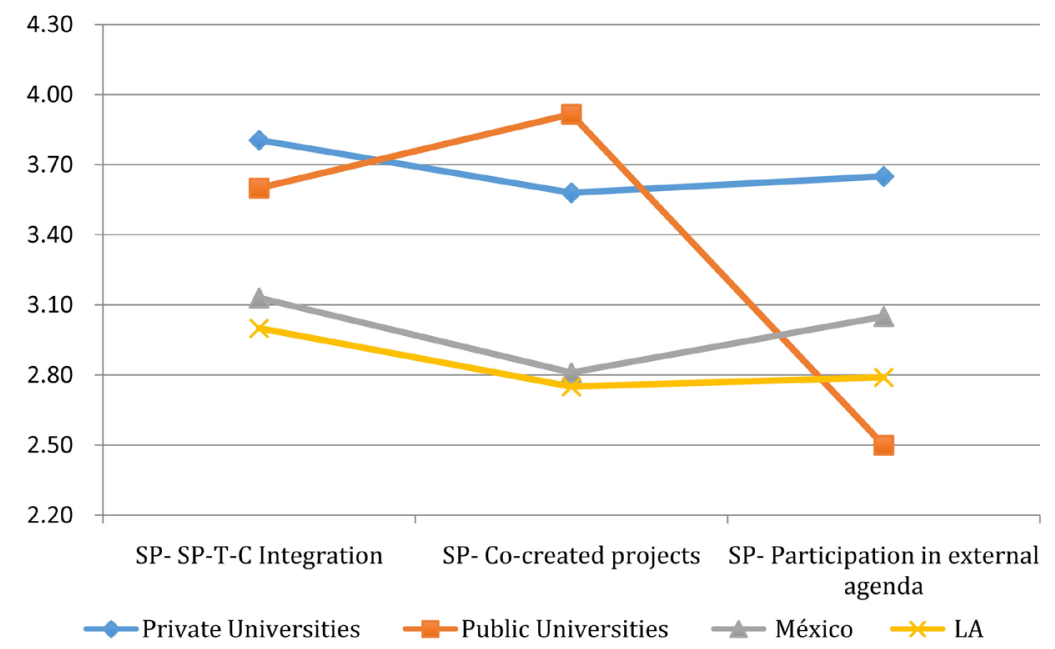

Figure 5. Comparative results of the participating universities in Social Participation. Note. Own elaboration based on (Vallaeys \& Solano, 2018); SP = Social Participation, LA $=$ Latin America. 
- Distrito Tec Initiative: It is a project that was started in 2014 and has an estimated duration of 15 years. The initiative is an urban regeneration, transformation, and evolution plan that will be integrated with adjacent ITESM neighborhoods, to create an ecosystem of innovation, entrepreneurship, and sustainability. Through this project, actions have been undertaken, such as Picnic Cinema, reforestation programs, $100 \%$ pedestrian traffic routes, drinking fountains, installation of electrical outlets, rehabilitation of streets, street (space for Sunday coexistence), and a constant dialogue with the inhabitants through boards of directors made up of neighbors. Likewise, the creation of pocket parks can be mentioned, which involved opening unused campus spaces to share them with the community.

- Multidisciplinary social service brigades in marginalized communities allow students to participate in research projects with high social impact.

- Change maker Campus recognition given by Ashoka, an international civil organization that promotes change through the promotion of social entrepreneurship in different sectors. Through its "Ashoka U” program, it identifies the leading universities in its field to solve the most important social problems. This recognition implies having processes, policies, and programs to promote innovation and social entrepreneurship through a connected internal and external ecosystem.

- The PERAJ program adopts a friend; it is a national program in which young university students carry out social service as mentors (one-to-one) of public primary children, supporting and motivating them to develop their maximum potential.

- Prepanet Initiative: This is an online high school program, the purpose of which is to help combat the country's educational backwardness. It is supported by students who provide advice to and resolve questions asked by Prepanet students.

\section{Discussions}

It is considered that, in the current reality, universities are called to play the role of change agents in society and respond to the needs of today's generations without compromising the future ones, not integrating the so-called USR in the management of HEIs, which means avoiding a commitment. The foregoing shows the undoubted relevance of USR in the current context (Aldeanueva, 2015; García \& Vega, 2019). An empirical, applied, non-experimental, and transversal research was conducted, with a mixed and descriptive approach, based on a survey of 201 managers; through this, the stated objectives were achieved. The first of these was to conduct a diagnosis of the progress level of USR management in the four participating universities, as shown in Table 6.

As Table 6 shows, UDEM shows the best performance in the management of USR, followed by ITESM, UCol, and UACH, which is the only one below the average of progress of the participating universities in the four areas of USR. The 
Table 6. Progress level of university social responsibility in participating Universities of Mexico.

\begin{tabular}{lccccc}
\hline \multicolumn{1}{c}{ Ambit/Goal } & ITESM & UDEM & UACH & UCol & Average \\
\hline Organizational Management (OM) & 3.73 & 4.29 & 3.09 & 3.71 & 3.71 \\
Training (T) & 2.94 & 4.30 & 2.21 & 2.54 & 3.00 \\
Cognition (C) & 3.29 & 4.22 & 2.89 & 4.06 & 3.61 \\
Social Participation (SP) & 3.11 & 4.25 & 2.91 & 3.77 & 3.51 \\
USR Progress Level & 3.27 & 4.26 & 2.78 & 3.52 & 3.46 \\
\hline
\end{tabular}

Note. Own elaboration; USR $=$ University Social Responsibility, ITESM $=$ Instituto Tecnológico y de Estudios Superiores de Monterrey, UDEM = Universidad de Monterrey, UACH = Universidad Autónoma de Chihuahua, UCol = Universidad de Colima.

lowest performance is seen in the field of Training.

Regarding the objective of comparing the USR performance of private and public HEIs, results of investigations were found (Vallaeys \& Solano, 2018) that even allowed comparing the performance of participating universities with HEIs in Mexico and Latin America. In this sense, we can highlight the work carried out in private universities, which show much higher performance than the averages for the mentioned regions. Even the participating public universities show performance above the averages for Mexico and Latin America in seven of the 12 USR goals analyzed. The main strengths of the diagnoses are presented in Table 7.

As Table 7 shows, the goals of good work environment and ethics and transparency in the OM field are perceived as strengths in all universities. The main areas of opportunity found in the diagnoses are presented in Table 8.

As it can be seen, the goal of including SDGs in study programs is a pending task for HEIs, despite the fact that the SGDs were published in 2015; though there has been progress, especially in private universities, it is necessary to pick up the pace. Ecological campus in the OM field is one of the goals perceived as an area of opportunity. It is necessary to work on raising awareness of the care of natural resources; in the field of training, another area of perceived opportunity, mainly in public universities, is the goal of roject-based learning-it implies that the link between HEIs and the productivpe sector is strengthened, and learning is based on solutions to real problems that occur in work environments.

Regarding the objective of identifying good USR practices in the participating universities, some important ones were focused on, especially in the OM field, related to governance of the universities among other work conditions that are far superior to those of the law, training and development plans for staff, code of ethics, gender equality, human rights defense, USR unit, organizational climate survey, etc.

Some recommendations for future research are as follows: carry out a broader comparative investigation of USR cross-management with other universities, not only national but also foreign, and create a bank of good practices that encourages the implementation of USR in HEIs. 
Table 7. Main strengths in the diagnosis of MSW in Latin America, Mexico, and public and private universities of Mexico.

\begin{tabular}{lcccc}
\multicolumn{1}{c}{ Scope/Goal } & $\begin{array}{c}\text { Private } \\
\text { Universities }\end{array}$ & $\begin{array}{c}\text { Public } \\
\text { Universities }\end{array}$ & Mexico & LA \\
\hline OM-Good work environment & 4.11 & 3.86 & 3.54 & 3.35 \\
OM-Ethics and transparency & 4.35 & 3.75 & 3.51 & 3.32 \\
T-Connections with external actors & 3.97 & & & \\
SP-Co-created projects & & 3.92 & & \\
SP-SP-F-I integration & & & 3.13 & \\
C-Inter and transdisciplinarity & & & & 3.06 \\
\hline
\end{tabular}

Note. Own elaboration; $\mathrm{OM}=$ Organizational Management, $\mathrm{T}=$ Training, $\mathrm{SP}=$ Social Participation, $\mathrm{C}=$ Cognition, LA = Latin America.

Table 8. Main areas of opportunity in the diagnosis of MSW in Latin America, Mexico, and public and private universities of Mexico.

\begin{tabular}{lcccc}
\multicolumn{1}{c}{ Scope/Goal } & $\begin{array}{c}\text { Private } \\
\text { Universities }\end{array}$ & $\begin{array}{c}\text { Public } \\
\text { Universities }\end{array}$ & Mexico & LA \\
\hline OM-Ecological campus & 3.57 & & 2.58 & 2.6 \\
T-Inclusion of SDGs & 3.23 & 1.84 & 2.55 & 2.18 \\
SP-Co-created projects & 3.58 & & & \\
SP-Participation in external agenda & & 2.5 & & \\
T-Project-based learning & & 2.43 & 2.55 & 2.66 \\
\hline $\begin{array}{l}\text { Note. Own elaboration; OM = Organizational Management, T }=\text { Training, SP = Social Participation, SDGs } \\
=\end{array}$ Sustainable Development Goals, LA = Latin America. & &
\end{tabular}

It is very important to mention that, in the course of the investigation, some limitations were detected, these are considered as opportunities by the authors of the present investigation and highlighting them positively impacts the development of other studies, these were: the sample included only managers, no interest groups that could provide interesting perceptions, such as students, teachers, or administrative staff. Similarly, the measurement instrument contains some elements of perception, in which respondents tend to respond according to their current knowledge and/or the ideal situation, and not according to what is really happening.

The results confirm modest performance in the evaluated macro-variable USR, the UDEM is the one that presents an outstanding performance, the other participating universities oscillate in a performance of 2 to 3 , that is, between isolated initiatives and the start of a joint effort that has not yet It has reached its institutionalization as a general policy and established organizational routines. It can be said that in the region it is a new concern, certainly on the rise, but not yet consolidated as a management system in Latin American HEIs. The example of what UDEM is doing in USR can generate much improvement in Mexico. 
Finally, it is necessary to emphasize that universities should not be separated from the needs of the society that supports them; they have a social voice that drives them to seek excellence in the training of professionals that the environment needs. More than ever, it is necessary to strengthen the premise that the vocation of HEIs is to be socially responsible, since only in this way can they be agents of change and promote the sustainable development of society.

\section{Acknowledgements}

We would like to thank Editage (http://www.editage.com/) for English language editing.

\section{Conflicts of Interest}

The authors declare no conflicts of interest regarding the publication of this paper.

\section{References}

Aldeanueva, I. (2015). Responsabilidad social universitaria: Realidad emergente en el ambito de la educacion superior. In I. Aldeanueva, O. Arango, I. Puerta, I. Amaro, M. Costa, C. Cardona et al. (Eds.), Experiencias iberoamericanas en responsabilidad social universitaria (p. 472). Fundacion Universitaria Luis Amigo.

Aldeanueva, I., \& Jiménez, J. (2013). Experiencias Internacionales en Materia de Responsabilidad Social Universitaria. Revista Cíentifica "Visión de Futuro", 17, 1-16.

Andrades, F., \& Larrán, M. (2015). Análisis de la responsabilidad social universitaria desde diferentes enfoques teóricos. Revista Iberoamericana De Educación Superior, 6, 91-107. https://doi.org/10.22201/iisue.20072872e.2015.15.144

Asociación Nacional de Facultades y escuelas de Contaduría y Administración ANFECA (2016). El Modelo de RSU en la ANFECA. ANFECA.

Beltrán, J., Íñigo, E., \& Mata, A. (2014). La responsabilidad social universitaria, el reto de su construccion permanente. Revista Iberoamericana de Educacion Superior, 5, 3-18. https://doi.org/10.22201/iisue.20072872e.2014.14.128

Cohen, D. (2007). Desafios de la Responsabilidad Social Universitaria. Razon y Palabra, No. 55.

Dominguez, M. (2009). Responsabilidad Social Universitaria. Humanismo y Trabajo Social, 8, 37-67.

Gaete, R. (2011). La responsabilidad social universitaria como desafío para la gestión estratégica de la Educación Superior: El Caso de España. Revista de Educación, 355, 109-133.

Gaete, R. (2015). La Responsabilidad Social Universitaria desde la Perspectiva de las Partes interesadas: Un Estudio de Caso. Actualidades Investigativas en Educacion, 15, 1-29. https://doi.org/10.15517/aie.v15i1.17729

Gaete, R. (2016). Iniciativas internacionales y redes interuniversitarias de responsabilidad social universitaria. Ciencia, Docencia y Tecnologia, 27, 75-102.

García, F., \& Vega, R. (2019). El Camino Hacia la Responsabilidad Social Universitaria en la Universidad Michoacana de San Nicolás de Hidalgo. In F. García, \& R. Vega (Eds.), Experiencias y aprendizajes de Responsabilidad Social Universitaria: Una mirada desde 
la Región Centro Occidente de la ANUIES (p. 239). Universidad Michoacana de San Nicolás de Hidalgo.

López, M., Zalthen, L., \& Cervantes, M. (2016). La Responsabilidad Social Universitaria desde la Perspectiva del Alumno. Ra Ximhai, 12, 305-314.

https://doi.org/10.35197/rx.12.01.e3.2016.20.ml

Martínez, P., \& Hernández, A. (2013). Responsabilidad social universitaria: Un desafío de la universidad pública mexicana. Contribuciones desde Coatepec, 24, 85-103.

Martínez, P., Escobedo, H., García, M., \& López, G. (2018). The Challenge of University Social Responsibility at the Autonomous University of Chihuahua. International Review of Management and Business Research, 7, 836-852.

https://doi.org/10.30543/7-4(2018)-6

Mendoza, D., Salas, E., \& López, D. (2015). Responsabilidad Social en Universidades Públicas Autónomas: Esencia Académica con Visión Transformadora. Clío América, 9, 135-142. https://doi.org/10.21676/23897848.1531

Moreno, M., \& Gutiérrez, D. (2018). Responsabilidad social universitaria en una escuela de negocios. ECORFAN-México.

Naciones Unidas (2015). Objetivos de Desarrollo Sostenible. https://www.un.org/sustainabledevelopment/es/objetivos-de-desarrollo-sostenible

Olarte, D., \& Ríos, L. (2015). Enfoques y estrategias de responsabilidad social implementadas en Instituciones de Educacion Superior. Una revision sistematica de la literatura cientifica de los ultimos 10 anos. Revista de la Educacion Superior, 44, 19-40. https://doi.org/10.1016/j.resu.2015.10.001

Pancenza, M., \& Silva, Y. (2013). Análisis bibliométrico sobre responsabilidad social universitaria. Psychology, Society, \& Education, 5, 293-306. https://doi.org/10.25115/psye.v5i2.500

Rusinko, C. (2010). Integrating Sustainability in Higher Education: A Generic Matrix. International Journal of Sustainability in Higher Education, 11, 250-259. https://doi.org/10.1108/14676371011058541

Schwalb, M., Prialé, M., \& Vallaeys, F. (2019). Guía de responsabilidad social universitaria. Universidad del Pacífico. https://doi.org/10.21678/978-9972-57-420-7

UNESCO (2009). UNESDOC Biblioteca Digital. Conferencia Mundial sobre la Educacion Superior 2009: La nueva dinamica de la educacion superior y la investigacion para el cambio social y el desarrollo.

http://www.unesco.org/education/WCHE2009/comunicado es.pdf

Vallaeys, F., \& Solano, D. (2018). URSULA. Resultados Investigación Continental URSULA: Estado del arte de la RSU en America Latina.

http://unionursula.org/wp-content/uploads/2018/10/informe-final-investigacion-conti nental-rsu-ursula-2018.pdf

Vallaeys, F., Solano, D., \& Oliveira, C. (2019). URSULA. Resultados Investigación Continental URSULA: Estado del Arte de la RSU en América Latina.

http://unionursula.org/wp-content/uploads/2020/04/informe-final-investigacion-conti nental-rsu-ursula-2019.pdf 